\title{
Effects of zopiclone on blood glucose level, serum lipid concentration and clot lysis time in normoglycemic and normolipidemic rats
}

\author{
J. Horák ${ }^{1}$, B. Cuparencu ${ }^{1}$, Aliz Horák ${ }^{2}$ \\ ${ }^{1}$ Department of Pharmacology, Faculty of Medicine and Pharmacy, University of Oradea, and \\ ${ }^{2}$ Institute of Oncology, Cluj Napoca, Romania \\ Received: April 27, 2001 \\ Accepted: August 17, 2001
}

\begin{abstract}
In normoglycemic and normolipidemic rats the i.p. injection of zopiclone induced an acceleration of fibrinolysis in a dose-dependent bell shaped manner and various changes of the blood glucose level. Total lipids, total cholesterol and triglyceride serum levels remained unaffected by doses of $1.25,2.5$ and $15.0 \mathrm{mg} / \mathrm{kg}$, with the exception of the medium dose $(5.0 \mathrm{mg} / \mathrm{kg})$ and the next dose $(10.0 \mathrm{mg} / \mathrm{kg})$ which lowered them very significantlly.
\end{abstract}

Keywords: zopiclone, rats, normoglycemia, normolipidemia, fibrinolysis, serum lipids, zopiclone, blood glucose level, total cholesterol

Zopiclone is a cyclopyrolone (CYP) acting upon the central benzodiazepine (BZD) receptors. It has the same pharmacological properties as BZD. It is used as a hypnotic (6). Our investigations have revealed that BZD, acting very probably, on the peripheral type BZD receptors have the property to lower serum lipids, mainly triglycerides, when they are elevated (for reviews see 1, 3, 7). In normolipidemic rats, the effects are manifested as either an increase of lipids or a decrease or no significant changes can be detected $(9,10)$. With regard to blood glucose, the results are heterogeneous $(9,10)$. The fibrinolysis, measured on the basis of diluted clot lysis time is either accelerated, or delayed, depending on the tested compound $(1,3,7)$.

In previous papers $(4,11)$ we have shown that zopiclone given to hyperlipidemic rats induced a very significant decrease of serum lipids. Blood glucose level was

Correspondence should be addressed to

Dr. József Horák

3400 Cluj Napoca, str. Ion Andreescu Nr. 7, Romania 
decreased at most of the doses. The pharmacological analysis has demonstrated that the antihyperlipidemic activity of zopiclone is very probably due to the stimulation of the peripheral type of BZD receptors (11).

In this paper, we present the results obtained in the course of an investigation devoted to the effects of zopiclone in normoglycemic and normolipidemic rats. The main purpose of this study was to see whether zopiclone affected the fibrinolysis, an important component of the mechanism which prevents one of the complications of atherosclerosis, the thrombosis. As to the results of our previous investigations $(1,3,7)$, the determination of fibrinolysis can be not carried out in Triton-WR-1339 treated rats. Therefore, we worked with normoglycemic and normolipidemic rats.

\section{Materials and Methods}

The experiments were carried out in male Wistar rats, weighing 150-200 g. Prior to experimental they received standard equilibrated diet with water ad libitum. The temperature $\left(20-22{ }^{\circ} \mathrm{C}\right)$ as well as the humidity were kept constant. The experimental protocol was follows:

1) The control, normoglycemic and normolipidemic group, consisting of 20 rats, was treated intraperitoneally (i.p.) with the mixture used for the suspension of zopiclone. Then mixture consisted of methyl cellulose $0.2 \%$ and glycerin $1 \%$. The animals were then fasting, but water was allowed ad libitum. Twenty hours after the i.p. injection, blood was sampled from the retroorbital sinus. From the blood and plasma, the following determinations were performed: 1 . Clot lysis time according to the method of Gallimore et al. (5). 2. Blood glucose level with the enzymatic procedure of Ashwell (Merck's test). 3. Total lipids with the technique of Zöllner and Kirsch. 4. Total cholesterol with the Reanal enzymatic test. 5. Triglycerides with the enzymatic procedure of Epstein (Merck's enzymatic test). The biochemical methods were described by Manta et al. (13).

The results were expressed as minutes for clot lysis time, as $\mathrm{mg} \%$ for total lipids and as mmoles/l for other parameters.

2) Another group (10 rats) received i.p. fenofibrate $(200 \mathrm{mg} / \mathrm{kg})$, as reference compound. The blood was collected 20 hours later. Determinations were the same as in the the control group.

3) Zopiclone groups: each dose $(0.25-2.5-5.0-10.0-15.0 \mathrm{mg} / \mathrm{kg})$ was tested separately in 10 rats. The experimental protocole was identical to that described for fenofibrate. The comparison of the results was performed in the following manner.

1. The results gained from zopiclone treatment at each dose were compared with the values obtained in the control group (p). 
2. The results gained gained from zopiclone treatment at each dose were compared with the values obtained in fenofibrate groups $\left(\mathrm{P}_{1}\right)$. The statistical evaluation was carried out by means of nonpaired " $t$ " test (15). Significance was admitted if $\mathrm{p}<0.05$.

\section{Results}

Clot lysis time

Fenofibrate failed to affect this parameter, whereas zopiclone diminished it very significantly, with the exception of the highest dose $(15.0 \mathrm{mg} / \mathrm{kg})$ which was ineffective (Table I).

Table I

The effects of zopiclone on blood glucose and lipid levels and fibrinolysis in normoglycemic and normolipidemic rats

\begin{tabular}{|c|c|c|c|c|c|}
\hline Group & $\begin{array}{c}\text { Clot lysis } \\
\text { time (minutes) }\end{array}$ & $\begin{array}{l}\text { Blood glucose } \\
\text { level (mmol/l) }\end{array}$ & $\begin{array}{l}\text { Total lipids } \\
\text { (mg \%) }\end{array}$ & $\begin{array}{l}\text { Total cholesterol } \\
(\mathrm{mmol} / \mathrm{l})\end{array}$ & $\begin{array}{c}\text { Triglycerides } \\
(\mathrm{mmol} / \mathrm{l})\end{array}$ \\
\hline $\begin{array}{l}\text { Control } \\
\text { Normolipidemic } \\
\text { and normoglycemic }\end{array}$ & $54.20 \pm 1.25$ & $3.34 \pm 0.210$ & $380.71 \pm 12.19$ & $1.651 \pm 0.08$ & $0.694 \pm 0.095$ \\
\hline $\begin{array}{l}\text { Fenofibrate } \\
(200 \mathrm{mg} / \mathrm{kg})\end{array}$ & $\begin{array}{l}49.66 \pm 3.14 \\
\text { p.n.s }\end{array}$ & $\begin{array}{l}4.02 \pm 0.115 \\
p<0.01\end{array}$ & $\begin{array}{l}372.40 \pm 12.70 \\
\text { p.n.s }\end{array}$ & $\begin{array}{l}1.68 \pm 0.065 \\
\text { p.n.s. }\end{array}$ & $\begin{array}{l}0.605 \pm 0.047 \\
\text { p.n.s }\end{array}$ \\
\hline $\begin{array}{c}\text { Zopiclone } \\
(1.25 \mathrm{mg} / \mathrm{kg})\end{array}$ & $\begin{array}{l}33.12 \pm 1.28 \\
\mathrm{p}<0.001 \\
\mathrm{p} 1<0.001\end{array}$ & $\begin{array}{l}3.12 \pm 0.24 \\
\text { p.n.s. } \\
\text { p1<0.001 }\end{array}$ & $\begin{array}{l}397.33 \pm 19.5 \\
\text { p.n.s } \\
\text { p1.n.s }\end{array}$ & $\begin{array}{l}1.85 \pm 0.11 \\
\text { p.n.s } \\
\text { p1.n.s }\end{array}$ & $\begin{array}{l}0.78 \pm 0.092 \\
\text { p.n.s. } \\
\text { p1.n.s }\end{array}$ \\
\hline $\begin{array}{c}\text { Zopiclone } \\
(2.50 \mathrm{mg} / \mathrm{kg})\end{array}$ & $\begin{array}{l}28.70 \pm 3.44 \\
\mathrm{p}<0.001 \\
\mathrm{p} 1<0.001\end{array}$ & $\begin{array}{l}3.44 \pm 0.124 \\
\text { p.n.s } \\
\text { p1<0.001 }\end{array}$ & $\begin{array}{l}402.40 \pm 20.30 \\
\text { p.n.s } \\
\text { p1.n.s }\end{array}$ & $\begin{array}{l}1.73 \pm 0.095 \\
\text { p.n.s } \\
\text { p1.n.s }\end{array}$ & $\begin{array}{l}0.72 \pm 0.074 \\
\text { p.n.s. } \\
\text { p1.n.s }\end{array}$ \\
\hline $\begin{array}{l}\text { Zopiclone } \\
(5.0 \mathrm{mg} / \mathrm{kg})\end{array}$ & $\begin{array}{l}38.75 \pm 2.65 \\
p<0.001 \\
p 1<0.001\end{array}$ & $\begin{array}{l}5.62 \pm 0.175 \\
\mathrm{p}<0.001 \\
\mathrm{p} 1<0.001\end{array}$ & $\begin{array}{l}310.25 \pm 15.40 \\
p<0.001 \\
\text { p } 1<0.001\end{array}$ & $\begin{array}{l}1.45 \pm 0.065 \\
p<0.001 \\
p 1<0.001\end{array}$ & $\begin{array}{l}0.43 \pm 0.035 \\
p<0.001 \\
p 1<0.001\end{array}$ \\
\hline $\begin{array}{c}\text { Zopiclone } \\
(10.0 \mathrm{mg} / \mathrm{kg})\end{array}$ & $\begin{array}{l}45.32 \pm 3.96 \\
p<0.001 \\
\text { p1.n.s }\end{array}$ & $\begin{array}{l}5.35 \pm 0.163 \\
\mathrm{p}<0.001 \\
\mathrm{p} 1<0.001\end{array}$ & $\begin{array}{l}298.40 \pm 13.75 \\
\text { p }<0.001 \\
\text { p } 1<0.001\end{array}$ & $\begin{array}{l}1.35 \pm 0.075 \\
\mathrm{p}<0.001 \\
\mathrm{p} 1<0.001\end{array}$ & $\begin{array}{l}0.35 \pm 0.044 \\
\mathrm{p}<0.001 \\
\mathrm{p} 1<0.001\end{array}$ \\
\hline $\begin{array}{c}\text { Zopiclone } \\
(15.0 \mathrm{mg} / \mathrm{kg})\end{array}$ & $\begin{array}{l}51.22 \pm 4.85 \\
\text { p.n.s } \\
\text { p1.n.s. }\end{array}$ & $\begin{array}{l}3.54 \pm 0.18 \\
\text { p.n.s } \\
\text { p1<0.001 }\end{array}$ & $\begin{array}{l}401.0 \pm 10.75 \\
\text { p.n.s } \\
\text { p1.n.s. }\end{array}$ & $\begin{array}{l}1.80 \pm 0.12 \\
\text { p.n.s } \\
\text { p1.n.s. }\end{array}$ & $\begin{array}{l}0.74 \pm 0.115 \\
\text { p.n.s } \\
\text { p1.n.s. }\end{array}$ \\
\hline
\end{tabular}

p compared with control normolipidemic rats

p1 compared with fenofibrate

n.s. not significant

Each group consisted from 10 rats with thw exception of the contol normoglycemic and normolipidemic which was composed from 20 rats 


\section{Blood glucose level}

Fenofibrate induced a very significant increase. At the same time, the changes of this parameter, induced by zopiclone, are irregular. So, the lowest dose $(1.25 \mathrm{mg} / \mathrm{kg})$, the next one $(2.5 \mathrm{mg} / \mathrm{kg})$ and the highest dose $(15.0 \mathrm{mg} / \mathrm{kg})$ elicited significant decreases. Nn the contrary the medium dose $(5.0 \mathrm{mg} / \mathrm{kg})$ and the next one $(10.0 \mathrm{mg} / \mathrm{kg})$ produced, very significant elevations (Table I).

\section{Total lipids}

Total lipids are not affected by fenofibrate and the first two doses of zopiclone $(1.25$ and $2.5 \mathrm{mg} / \mathrm{kg})$. The reduction of this parameter was highly significant at the medium and the next doses of zopiclone. The highest dose had no significant effect (Table I).

\section{Total cholesterol and triglycerides}

Total cholesterol and triglycerides behaved like total lipids (Table I).

\section{Discussion}

Our previous experiments, carried out in hyperlipidemic rats (hyperlipidemia was induced by an i.p. injection of $200 \mathrm{mg} / \mathrm{kg}$ Triton WR-1339, blood was sampled 18 hours thereafter) have shown that zopiclone, administered in the same doses as in the present investigation, induced a marked decrease of the serum lipids, while blood glucose was decreased by most doses (11). The effects on fibrinolysis were not studied in Triton WR-1339 induced hyperlipidemia since this tensioactive substance elicited a remarkable acceleration of fibrinolysis by itself $(1,3,7)$.

Other studies revealed that diazepam administered in normoglycemic and normolipidemic rats brought about an acceleration of fibrinolysis (8). The same effects were observed in normal humans. Midazolam also enhanced fibrinolysis (10) when given in normoglycemic and normolipidemic rats. Chlordiazepoxide and dipotassium clorazepate were ineffective or less active (14), depending on the dose and the duration of administration. Lorazepam had an inhibitory action. An acceleration of the fibrinolysis was observed also with diazepam administered in margarine induced hyperlipidemia in rats as well as in hyperlipidemic humans (2). Since all the mentioned drugs 
had marked lipid lowering activity in hyperlipidemic conditions, but had inconsistent effect in normolipidemic rats and humans. There is no correlation between changes of fibrinolysis and serum lipids.

Zopiclone, as well as given BZD in hyperlipidemic rats induced a marked decrease of serum lipids. This effect seems to be due to the stimulation of the peripheral type BZD receptors, since PK 11195, a selective antagonist of these receptors, abolished it (11). At the same time, flumazenil, a selective antagonist of the central BZD receptors, failed to inhibit the lipid lowering activity of this compound (11). The mechanism by which the stimulation of the peripheral type- BZD receptors induce a fall of the serum lipids is not known. In the literature there are data which indicate that these receptors are responsible for cholesterol catabolism to a large extent (12). However, the effects on triglycerides have remained unexplained so far.

We don't know why BZD had only a modest or no lipid lowering action in normolipidemic conditions, while in hyperlipidemic subjects they exerted a potent hypolipidemic effect. It seems reasonable to admit that in hyperlipidemic conditions the peripheral type BZD receptors are found in a conformation which would render them more susceptible to the action of BZD and to that of drugs acting upon the same receptors as zopiclone.

The effects on blood glucose level and on fibrinolysis are independent from those on serum lipids level. This confirms our previous results $(8,10)$ which have shown that BZD induced independent changes of fibrinolysis, serum lipids and blood glucose level.

\section{Acknowledgements}

The authors are greatly indebted to Rhone-Poulenc (Paris, France) and to Ratiopharm (Ulm, Germany) for the generous gifts of zopiclone and fenofibrate, respectively.

\section{REFERENCES}

1. Cuparencu B: Benzodiazepines as an experimental treatment of hyperlipidemia. Rend. Atti. Accad. Sci. Med. Chir., Napoli 140, 71-105 (1986)

2. Cuparencu B, Horák J, Cucuianu M, Hâncu N, Negru S, Seuşan E, Vincze J: Effects of some benzodizepine derivatives on fibrinolysis and serum lipids in normolipidemic rats and humans. Atherosclerosis 31, 435-441 (1978)

3. Cuparencu B, Pleşca L (1995): Advances in Pharmacology and Pathophysiology (Actualităţi in Farmacologie şi Fiziopatologie-in Romanian), Ed. Dacia, Cluj Napoca, pp. 264-275.

4. Cuparencu B, Horák J, Horák A, Ţiglea M: Acute effects of Zopiclone on blood glucose level and serum lipids in hyperlipidemic rats. Acta Physiol. Hung. 87, 193-199 (2000)

5. Gallimore MJ, Tyler HM, Shaw IT: The measurement of fibrinolysis in the rats. Throm. Diath. Haemorrh. 26, 293-310 (1971) 
6. Goa KL, Heel RC: Zopiclone. Review of its pharmacodynamic and pharmacokinetic properties and therapeutic efficacy as a hypnotic drug. Drugs 32, 48-65 (1986)

7. Hâncu N, Cuparencu B, Duțu A (1988): Pharmacotherapy of atherosclerosis. (Farmacoterapia aterosclerozei - in Romanian) Ed. Med., Bucharest, pp. 56-67.

8. Horák J, Cuparencu B, Cucuianu M, Ispas G: Activité profibrinolytique de certaines benzodiazépines chez les rats et les sujets hypérlipidémique. Thérapie 42, 197-200 (1987)

9. Horák J, Cuparencu B, Esposito G, Stella L, Marmo E: Effects of the intraperitoneal administration of chlorazepate, oxazepam and medazepam on serum glucose and lipids in normoglycemic and normolipidemic rats. Curr. Ther. Res. 51, 351-368 (1992)

10. Horák A, Cuparencu B, Horák J, Lenghel A: Effects of midazolam on blood glucose, fibrinolysis, serum lipids in normoglycemic - normolipidemic rats. Acta Physiol. Hung. 84, 217-221 (1996)

11. Horák J, Cuparencu B, Horák A: Acute effects of zopiclone on blood glucose level and serum lipids in hyperlipidemic rats. Interactions with PK 11195 and flumazenil. Acta Physiol. Hung. 87, 185-195 (2000)

12. Kruege KE, Papadopoulos V: Mitochondrial benzodiazepine receptor. Ann. Rev. Pharmacol. Toxicol. 32, 211-237 (1992)

13. Manta M, Cucuianu M, Benga Gh, Hodârnǎu A, (1976): Biochemical methods in clinical laboratory (Metode biochimice în laboratorul clinic. In Romanian), Ed. Dacia, Cluj Napoca

14. Petrescu M, Cuparencu B, Horák J, Petrescu L, Florescu P, Kory M, Tomuş C: Certain aspects of toxicity of some benzodiazepines. Agressologie 22, 209-215 (1984)

15. Snedecor GW, Cochran WG (1978): Statistical Methods, VI Ed. Iowa Univ. Press., Ames, Iowa, USA 